Brit. J. industr. Med., 1958, 15, 217.

\title{
CANCER OF THE LUNG AND NOSE IN NICKEL WORKERS
}

\author{
BY \\ RICHARD DOLL \\ From the Statistical Research Unit, Medical Research Council, London
}

(RECEIVED FOR PUBLICATION FEBRUARY 4, 1958)

In 1949 the Minister of Pensions and National Insurance of Great Britain prescribed cancer of the lung and cancer of the nose as industrial diseases, when they occurred among certain classes of workers engaged in the refining of nickel. The published epidemiological evidence regarding the hazard is, however, scanty. It consists only of a series of case reports (Amor, 1939; Løken, 1950) and a statement of the total number of cases which occurred between 1923 and 1950 and were reported to the Ministry (Chief Inspector of Factories, 1952). The present investigation was, therefore, undertaken to obtain evidence relating to (1) the magnitude of the risk, and (2) the belief that the risk had been eliminated from the refinery concerned between 1920 and 1924.

The data for the investigation were obtained from the records of death held by the medical officers of health of the districts in which the workers at the refinery lived. These records included copies of the death certificates of all persons dying in the districts and also of the certificates of persons resident in the districts, who had died elsewhere. Since the majority of the workers live in the Pontardawe Rural District of the County of Glamorganshire and a few others live in the County Borough of Swansea and in two other neighbouring districts, it was possible to obtain information about the causes of death of nearly all-if not of all-the workers who died during employment at the refinery and of a large proportion of the retired workers who had worked at the refinery when they had last been employed. These data can be compared with the national data for the different causes of death during the same period or with similar data for the same districts, but relating to men in other occupations. In the present study, it was thought better to use the other data from the same districts, when they were numerically adequate, as by this means it was possible to eliminate differences in the incidence of the two diseases due to non-industrial local factors.
Data for the 15,247 men over the age of 15 years who were resident in the four selected districts and who died in the period 1948-56 are shown in Table 1. The numbers of deaths are shown separately for three causes, five occupational groups, and 13 age groups. The causes have been classified as cancer of the lung, cancer of the nose, or " other causes" according to the diagnosis given on the death certificate. Where two or more causes were referred to the death has been classified to the underlying cause, in accordance with international usageexcept in 10 instances in which a primary cancer of the lung was given as an associated disease, when the death was classified as if it had been attributable to the cancer. The numbers of cases in each occupational and age group in which the international usage was varied are shown in Table 1. The five occupational groups consist of nickel, steel, and colliery workers, men employed in certain "other selected occupations", and those in all other occupations. The men in "other selected occupations" were employed at an oil refinery or were described as aluminium, copper, spelter or " patent fuel " workers; they were studied separately because it was thought possible that one or other of these industries might also carry a specific risk of lung cancer.

The death records for earlier periods were available in the offices of the medical officers of health for only two of the four areas studied; one of them was, however, the area in which the refinery is situated and in which the majority of the nickel workers resided. Data for these two areas for the period 1938-47 are shown in Table 2: the corresponding data for the period 1948-56 (included in Table 1) are also shown in Table 2 for comparison. The data are shown in the same way as in Table 1, save that, because of the smaller numbers, they are given in larger age groups. 
TABLE 1

NUMBER OF DEATHS FROM CANCER OF LUNG AND OF NOSE AND OTHER CAUSES AMONG MEN RESIDENT IN FOUR LOCAL AUTHORITY AREAS IN SOUTH WALES (1948-1956) SUBDIVIDED BY AGE AND NATURE OF LAST EMPLOYMENT

\begin{tabular}{|c|c|c|c|c|c|c|c|c|c|c|c|c|c|c|c|c|c|c|c|}
\hline \multirow{3}{*}{$\begin{array}{c}\text { Age at Death } \\
\text { (years) }\end{array}$} & \multicolumn{15}{|c|}{ Number of Deaths among Men Employed in: } & \multirow{2}{*}{\multicolumn{4}{|c|}{ All Occupations }} \\
\hline & \multicolumn{3}{|c|}{$\begin{array}{c}\text { Nickel } \\
\text { Industry }\end{array}$} & \multicolumn{3}{|c|}{$\begin{array}{l}\text { Other Selected } \\
\text { Occupations* }\end{array}$} & \multicolumn{3}{|c|}{$\begin{array}{c}\text { Steel } \\
\text { Industry }\end{array}$} & \multicolumn{3}{|c|}{ Coal-mining } & \multicolumn{3}{|c|}{$\begin{array}{l}\text { All Other } \\
\text { Occupations }\end{array}$} & & & & \\
\hline & $\begin{array}{l}\text { Cancer } \\
\text { of } \\
\text { Lung }\end{array}$ & $\begin{array}{c}\text { Cancer } \\
\text { of } \\
\text { Nose }\end{array}$ & $\begin{array}{c}\text { Other } \\
\text { Causes }\end{array}$ & $\begin{array}{l}\text { Cancer } \\
\text { of } \\
\text { Lung }\end{array}$ & $\mid \begin{array}{c}\text { Cancer } \\
\text { of } \\
\text { Nose }\end{array}$ & $\begin{array}{l}\text { Other } \\
\text { Causes }\end{array}$ & $\begin{array}{l}\text { Cancer } \\
\text { of } \\
\text { Lung }\end{array}$ & $\begin{array}{c}\text { Cancer } \\
\text { of } \\
\text { Nose }\end{array}$ & $\begin{array}{c}\text { Other } \\
\text { Causes }\end{array}$ & \begin{tabular}{|c|} 
Cancer \\
of \\
Lung
\end{tabular} & $\begin{array}{c}\text { Cancer } \\
\text { of } \\
\text { Nose }\end{array}$ & $\begin{array}{l}\text { Other } \\
\text { Causes }\end{array}$ & $\begin{array}{l}\text { Cancer } \\
\text { of } \\
\text { Lung }\end{array}$ & $\begin{array}{c}\text { Cancer } \\
\text { of } \\
\text { Nose }\end{array}$ & $\begin{array}{c}\text { Other } \\
\text { Causes }\end{array}$ & $\begin{array}{l}\text { Cancer } \\
\text { of } \\
\text { Lung }\end{array}$ & $\begin{array}{c}\text { Cancer } \\
\text { of } \\
\text { Nose }\end{array}$ & $\begin{array}{l}\text { Other } \\
\text { Causes }\end{array}$ & $\begin{array}{c}\text { All } \\
\text { Causes }\end{array}$ \\
\hline $\begin{array}{c}15- \\
25- \\
35- \\
45- \\
50- \\
55- \\
60- \\
65- \\
70- \\
75- \\
80- \\
85 \text { and over } \\
\text { Not stated }\end{array}$ & $\begin{array}{r}0 \\
0 \\
0 \\
1 \\
11 \\
11 \\
15 \\
8 \\
2 \\
0 \\
0 \\
0 \\
0\end{array}$ & $\begin{array}{l}\mathbf{0} \\
0 \\
0 \\
0 \\
1 \\
1 \\
2 \\
7 \\
1 \\
1 \\
0 \\
0 \\
0\end{array}$ & $\begin{array}{r}1 \\
4 \\
6 \\
3 \\
16 \\
22 \\
13 \\
13 \\
28 \\
19 \\
21 \\
6 \\
0 \\
0\end{array}$ & $\begin{array}{r}0 \\
0 \\
1 \\
6 \\
8 \\
9 \\
18 \\
7 \\
4 \\
1 \\
0 \\
0 \\
0\end{array}$ & $\begin{array}{l}0 \\
0 \\
0 \\
0 \\
0 \\
0 \\
0 \\
1 \\
0 \\
0 \\
0 \\
0 \\
0\end{array}$ & $\begin{array}{r}2 \\
23 \\
17 \\
34 \\
54 \\
67 \\
79 \\
86 \\
85 \\
78 \\
47 \\
33 \\
1\end{array}$ & $\begin{array}{l}0 \\
0 \\
2 \\
10 \\
15 \dagger \\
17 \dagger \\
32 \\
28 \dagger \\
10 \\
5 \\
2 \\
0 \\
0\end{array}$ & $\begin{array}{l}\mathbf{0} \\
0 \\
0 \\
1 \\
0 \\
\mathbf{0} \\
\mathbf{0} \\
\mathbf{0} \\
\mathbf{0} \\
\mathbf{0} \\
\mathbf{1} \\
1 \\
0\end{array}$ & $\begin{array}{r}12 \\
15 \\
63 \\
64 \\
105 \\
158 \\
233 \\
318 \\
352 \\
361 \\
251 \\
119 \\
4\end{array}$ & $\begin{array}{c}0 \\
0 \\
2 \\
4 \\
13 \\
8 \\
16 \dagger \\
10 \\
12 \ddagger \\
6 \\
1 \\
0 \\
1\end{array}$ & $\begin{array}{l}0 \\
0 \\
0 \\
0 \\
0 \\
0 \\
0 \\
1 \\
1 \\
0 \\
0 \\
0 \\
0\end{array}$ & $\begin{array}{r}16 \\
47 \\
104 \\
99 \\
158 \\
201 \\
336 \\
399 \\
470 \\
463 \\
302 \\
133 \\
1\end{array}$ & $\begin{array}{c}0 \\
5 \\
14 \\
40 \\
68 \\
87 \\
106 \ddagger \\
94 \\
59 \ddagger \\
23 \\
6 \\
1 \\
0\end{array}$ & $\begin{array}{l}\mathbf{0} \\
0 \\
0 \\
0 \\
0 \\
5 \\
0 \\
0 \\
1 \\
0 \\
0 \\
0 \\
0\end{array}$ & $\begin{array}{r}141 \\
214 \\
373 \\
365 \\
510 \\
778 \\
1,041 \\
1,328 \\
1,378 \\
1,314 \\
916 \\
525 \\
11\end{array}$ & $\begin{array}{r}0 \\
5 \\
19 \\
61 \\
115 \\
132 \\
187 \\
147 \\
87 \\
35 \\
9 \\
1 \\
1\end{array}$ & $\begin{array}{l}0 \\
0 \\
0 \\
1 \\
1 \\
6 \\
2 \\
9 \\
3 \\
1 \\
1 \\
1 \\
0\end{array}$ & $\begin{array}{r}171 \\
299 \\
564 \\
565 \\
844 \\
1,226 \\
1,702 \\
2,159 \\
2,303 \\
2,237 \\
1,526 \\
810 \\
17\end{array}$ & $\begin{array}{r}171 \\
304 \\
583 \\
627 \\
960 \\
1,364 \\
1,891 \\
2,315 \\
2,393 \\
2,273 \\
1,536 \\
812 \\
18\end{array}$ \\
\hline $\begin{array}{l}\text { All ages: } \\
15 \text { and over }\end{array}$ & 48 & 13 & 139 & 54 & 1 & 606 & 121 & 3 & 2,055 & 73 & 2 & 2,729 & 503 & 6 & 8,894 & 799 & 25 & 14,423 & 15,247 \\
\hline
\end{tabular}

*Men employed in aluminium, copper, spelter, and " patent fuel" works and in oil refineries.

$\dagger$ Including one case ( $¥$ two cases) in which primary lung cancer was referred to as an associated condition and not as the direct cause of death.

Cancer of the Lung

From the data shown in Table 1 it is, of course, impossible to calculate death rates, since the numbers of men employed in the different occupations are not known. If, however, the experience of one of the occupational groups is used as a standard, it is possible to estimate the numbers of deaths expected to be due to lung cancer in the other groups. The most suitable group to use in this way is the group of men employed in " all other occupations". The

TABLE 2

NUMBERS OF DEATHS FROM CANCER OF LUNG AND OF NOSE AND OTHER CAUSES AMONG MEN RESIDENT IN TV LOCAL AUTHORITY AREAS IN SOUTH WALES (1938-47 AND 1948-56) SUBDIVIDED BY AGE AND NATURE OF LAST EMPLOYME

\begin{tabular}{|c|c|c|c|c|c|c|c|c|c|c|c|c|c|c|c|c|c|c|c|c|}
\hline \multirow[b]{3}{*}{ Period } & \multirow{3}{*}{$\begin{array}{c}\text { Age } \\
\text { at } \\
\text { Death } \\
\text { (years) }\end{array}$} & \multicolumn{19}{|c|}{ Number of Deaths among Men Employed in: } \\
\hline & & \multicolumn{3}{|c|}{$\begin{array}{l}\text { Nickel } \\
\text { Industry }\end{array}$} & \multicolumn{3}{|c|}{$\begin{array}{l}\text { Other Selected } \\
\text { Occupations* }\end{array}$} & \multicolumn{3}{|c|}{$\begin{array}{c}\text { Steel } \\
\text { Industry }\end{array}$} & \multicolumn{3}{|c|}{ Coal-mining } & \multicolumn{3}{|c|}{$\begin{array}{l}\text { All Other } \\
\text { Occupations }\end{array}$} & \multicolumn{4}{|c|}{$\begin{array}{c}\text { All } \\
\text { Occupations }\end{array}$} \\
\hline & & $\begin{array}{c}\text { Cancer } \\
\text { of } \\
\text { Lung }\end{array}$ & $\begin{array}{c}\text { Cancer } \\
\text { of } \\
\text { Nose }\end{array}$ & $\begin{array}{c}\text { Other } \\
\text { Causes }\end{array}$ & $\begin{array}{c}\text { Cancer } \\
\text { of } \\
\text { Lung }\end{array} \mid$ & $\begin{array}{c}\text { Cancer } \\
\text { of } \\
\text { Nose }\end{array}$ & $\begin{array}{c}\text { Other } \\
\text { Causes }\end{array}$ & $\begin{array}{c}\text { Cancer } \\
\text { of } \\
\text { Lung }\end{array}$ & $\begin{array}{c}\text { Cancer } \\
\text { of } \\
\text { Nose }\end{array}$ & $\begin{array}{c}\text { Other } \\
\text { Causes }\end{array}$ & $\begin{array}{l}\text { Cancer } \\
\text { of } \\
\text { Lung }\end{array}$ & $\begin{array}{c}\text { Cancer } \\
\text { of } \\
\text { Nose }\end{array}$ & $\begin{array}{c}\text { Other } \\
\text { Causes }\end{array}$ & $\begin{array}{c}\text { Cancer } \\
\text { of } \\
\text { Lung }\end{array}$ & $\begin{array}{c}\text { Cancer } \\
\text { of } \\
\text { Nose }\end{array}$ & $\begin{array}{l}\text { Other } \\
\text { Causes }\end{array}$ & $\begin{array}{l}\text { Cancer } \\
\text { of } \\
\text { Lung }\end{array}$ & $\begin{array}{c}\text { Cancer } \\
\text { of } \\
\text { Nose }\end{array}$ & $\begin{array}{l}\text { Other } \\
\text { Causes }\end{array}$ & $\begin{array}{c}\text { All } \\
\text { Causes }\end{array}$ \\
\hline \multirow[t]{4}{*}{$\begin{array}{c}1938 \\
\text { to } \\
1947\end{array}$} & \multirow{3}{*}{$\begin{array}{c}15- \\
25- \\
35- \\
45- \\
55- \\
65- \\
75 \text { and } \\
\text { over } \\
\text { Not } \\
\text { stated }\end{array}$} & $\begin{array}{r}0 \\
0 \\
0 \\
14 \\
16 \\
6\end{array}$ & $\begin{array}{r}0 \\
0 \\
0 \\
2 \\
12 \\
2\end{array}$ & $\begin{array}{r}2 \\
2 \\
7 \\
23 \\
36 \\
20\end{array}$ & $\begin{array}{l}\mathbf{0} \\
\mathbf{0} \\
0 \\
\mathbf{0} \\
\mathbf{0} \\
\mathbf{0}\end{array}$ & $\begin{array}{l}0 \\
0 \\
0 \\
0 \\
0 \\
0\end{array}$ & $\begin{array}{r}0 \\
6 \\
6 \\
8 \\
12 \\
8\end{array}$ & $\begin{array}{l}0 \\
0 \\
2 \\
9 \\
7 \\
4 \dagger\end{array}$ & $\begin{array}{l}\mathbf{0} \\
\mathbf{0} \\
\mathbf{0} \\
\mathbf{0} \\
\mathbf{0} \\
\mathbf{1}\end{array}$ & $\begin{array}{r}17 \\
39 \\
53 \\
77 \\
176 \\
241\end{array}$ & $\begin{array}{l}0 \\
0 \\
1 \\
1 \\
3 \\
2\end{array}$ & $\begin{array}{l}0 \\
0 \\
0 \\
0 \\
0 \\
0\end{array}$ & $\begin{array}{r}28 \\
48 \\
69 \\
154 \\
271 \\
311\end{array}$ & $\begin{array}{r}0 \\
0 \\
0 \\
9 \\
13 \\
5\end{array}$ & $\begin{array}{l}\mathbf{0} \\
\mathbf{0} \\
\mathbf{0} \\
0 \\
1 \\
1\end{array}$ & $\begin{array}{r}62 \\
82 \\
94 \\
189 \\
390 \\
455\end{array}$ & $\begin{array}{r}0 \\
0 \\
3 \\
33 \\
39 \\
17\end{array}$ & $\begin{array}{r}0 \\
0 \\
0 \\
2 \\
13 \\
4\end{array}$ & $\begin{array}{r}109 \\
177 \\
229 \\
451 \\
885 \\
1,035\end{array}$ & $\begin{array}{r}109 \\
177 \\
232 \\
486 \\
937 \\
1,056\end{array}$ \\
\hline & & $\boldsymbol{0}$ & 0 & 2 & 0 & $\mathbf{0}$ & 5 & $\mathbf{0}$ & $\mathbf{0}$ & 201 & 1 & 1 & 190 & 2 & 0 & 428 & 3 & 1 & 826 & 830 \\
\hline & & - & - & - & - & - & 1 & - & - & - & - & 一 & - & - & - & - & - & - & 1 & 1 \\
\hline & $\begin{array}{l}\text { All ages } \\
15 \text { years } \\
\text { and over }\end{array}$ & 36 & 16 & 92 & 0 & 0 & 46 & 22 & 1 & 804 & 8 & 1 & 1,071 & 29 & 2 & 1,700 & 95 & 20 & 3,713 & 3,828 \\
\hline \multirow[t]{4}{*}{$\begin{array}{l}1948 \\
\text { to } \\
1956\end{array}$} & \multirow{3}{*}{$\begin{array}{c}15- \\
25- \\
35- \\
45- \\
55- \\
65- \\
75 \text { and } \\
\text { over } \\
\text { Not } \\
\text { stated }\end{array}$} & $\begin{array}{r}0 \\
0 \\
0 \\
9 \\
21 \\
9\end{array}$ & $\begin{array}{l}\mathbf{0} \\
\mathbf{0} \\
\mathbf{0} \\
\mathbf{1} \\
\mathbf{3} \\
\mathbf{8}\end{array}$ & $\begin{array}{r}0 \\
2 \\
4 \\
12 \\
24 \\
37\end{array}$ & $\begin{array}{l}\mathbf{0} \\
\mathbf{0} \\
\mathbf{0} \\
\mathbf{3} \\
\mathbf{2} \\
\mathbf{0}\end{array}$ & $\begin{array}{l}\mathbf{0} \\
\mathbf{0} \\
\mathbf{0} \\
\mathbf{0} \\
\mathbf{0} \\
\mathbf{0}\end{array}$ & $\begin{array}{r}1 \\
2 \\
2 \\
17 \\
12 \\
21\end{array}$ & $\begin{array}{c}0 \\
0 \\
1 \\
10 \dagger \\
13 \\
18 \dagger\end{array}$ & $\begin{array}{l}\mathbf{0} \\
0 \\
0 \\
0 \\
0 \\
0\end{array}$ & $\begin{array}{r}3 \\
3 \\
21 \\
55 \\
151 \\
256\end{array}$ & $\begin{array}{l}0 \\
0 \\
1 \\
6 \\
8 \dagger \\
8 \ddagger\end{array}$ & $\begin{array}{l}\mathbf{0} \\
\mathbf{0} \\
\mathbf{0} \\
\mathbf{0} \\
\mathbf{0} \\
\mathbf{2}\end{array}$ & $\begin{array}{r}4 \\
14 \\
47 \\
117 \\
220 \\
347\end{array}$ & $\begin{array}{c}0 \\
1 \\
2 \\
18 \\
30 \\
31 \dagger\end{array}$ & $\begin{array}{l}\mathbf{0} \\
0 \\
0 \\
0 \\
1 \\
0\end{array}$ & $\begin{array}{r}28 \\
43 \\
78 \\
161 \\
353 \\
533\end{array}$ & $\begin{array}{r}0 \\
1 \\
4 \\
46 \\
74 \\
66\end{array}$ & $\begin{array}{r}0 \\
0 \\
0 \\
1 \\
4 \\
10\end{array}$ & $\begin{array}{r}36 \\
64 \\
152 \\
362 \\
760 \\
1,194\end{array}$ & $\begin{array}{r}36 \\
65 \\
156 \\
409 \\
838 \\
1,270\end{array}$ \\
\hline & & 0 & 1 & 18 & 0 & 0 & 3 & 3 & 1 & 308 & 0 & 0 & 334 & 6 & 0 & 589 & 9 & 2 & 1,252 & 1,263 \\
\hline & & - & - & - & - & - & - & - & - & - & - & - & - & - & 1 & - & - & - & - & - \\
\hline & $\begin{array}{l}\text { All ages } \\
15 \text { years } \\
\text { and over }\end{array}$ & 39 & 13 & 97 & 5 & 0 & 58 & 45 & 1 & 797 & 23 & 2 & 1,083 & 88 & 1 & 1,785 & 200 & 17 & 3,820 & 4,037 \\
\hline
\end{tabular}

*Men employed in aluminium, copper, spelter, and " patent fuel" works and in oil refineries.

†Including one case ( $¥$ two cases) in which primary lung cancer was referred to as an associated condition and not as the direct cause of death. 
number of deaths is large and the types of occupation are numerous and varied; the total mortality of the group is, therefore, unlikely to have been influenced to any great extent by any single occupational factor. The number of deaths expected to be due to lung cancer in the other occupational groups may then be estimated by assuming that the ratio between the number due to lung cancer and the number due to " other causes", that is, all causes, other than cancer of the lung or nose, should be the same, at each age, as in the standard group. For example, there were 87 deaths due to lung cancer and 778 deaths due to "other causes" among men aged 55-59 years employed in "all other occupations ". There were 22 deaths due to "other causes" among men of the same ages employed in the nickel industry and it is, therefore, estimated that the expected number of deaths from lung cancer among the nickel workers is $\frac{87}{778} \times 22$, i.e., $2 \cdot 46$. The number actually observed was 11 . The results obtained by calculating the expected numbers for each of the age groups studied and summing for all ages are shown in Table 3*. Among the nickel workers the number of lung cancer deaths observed was nearly five times the number expected. Among the steel workers and the workers in the group of " other selected occupations ", the observed numbers were close to, but slightly higher than, the expected numbers; among the colliery workers the observed number was substantially less.

TABLE 3

COMPARISON BETWEEN OBSERVED AND EXPECTED NUMBERS OF DEATHS FROM CANCER OF LUNG IN FOUR NUMBERS OF DEATHS FROM CANCER OF
OCCUPATIONAL GROUPS

\begin{tabular}{l|c|c|c|c}
\hline No. of Deaths & $\begin{array}{c}\text { Nickel } \\
\text { Workers }\end{array}$ & $\begin{array}{c}\text { Men in Other } \\
\text { Selected Occupations }\end{array}$ & $\begin{array}{c}\text { Steel } \\
\text { Workers }\end{array}$ & $\begin{array}{l}\text { Colliery } \\
\text { Workers }\end{array}$ \\
\hline $\begin{array}{c}\text { Expected from } \\
\text { the experience } \\
\text { of men in " all } \\
\text { other occupa- } \\
\text { tions" }\end{array}$ & 9.88 & $39 \cdot 12$ & $110 \cdot 97$ & $152 \cdot 16$ \\
$\begin{array}{l}\text { Observed } \\
\text { Observed as \% } \\
\text { of expected }\end{array}$ & 486 & 138 & 121 & 73 \\
\hline
\end{tabular}

In this investigation, which is essentially a study of proportional mortality, a number of alternative explanations of the results are possible. The proportion of lung cancer deaths among the standard population may be abnormally low, the number of deaths from "other causes" among the nickel workers may be abnormally few, or the deaths from lung cancer may be excessive. The first explanation can be dismissed, since the proportion of lung cancer

\footnotetext{
*The few men whose ages at death were not known were presumed to have been distributed among the age groups in the same proportions as the men whose ages were known.
}

deaths in the standard population was very close to that which would have been expected on the basis of the mortality data for the whole country. From the national data it can be calculated that 493 deaths from lung cancer would be expected to have accompanied the 8,894 deaths from causes other than cancer of the lung and nose which occurred at the ages shown in Table 1; in fact, the number of lung cancer cases was 503 and the number in which death was certified as due to lung cancer was 499 , which is almost identical with the number expected. Moreover, it may be noted that the experience of the standard population leads to estimates for the expected numbers of lung cancer deaths among two of the other groups of " non-nickel " workers which are reasonably close to the numbers observed. For the second explanation to be valid, it would be necessary for the mortality among nickel workers from all " other causes" to be only one-fifth of the national mortality-and this is certainly unreasonable. From knowledge of the mortality of industrial workers in general it is, on the contrary, more likely that by virtue of their social status, the total " other cause " mortality of the nickel workers was somewhat higher than that in the non-industrial sections of the community.

It is extremely unlikely that any substantial proportion of the deaths attributed to lung cancer were falsely diagnosed as a result of a bias in favour of diagnosing lung cancer among nickel workers. For if this had been so, it must be presumed that there would have been a deficiency of deaths attributed to those other causes which could most easily be confused with cancer of the lung, namely, other types of cancer and other respiratory diseases. In fact, of the 139 deaths among nickel workers during the period 1948-56, which were not attributed to cancer of the lung or cancer of the nose, 25 were attributed to other types of cancer and 21 to other respiratory diseases. Data for the causes of death, other than what was required to place them in one of the other categories shown in Tables 1 and 2, were not extracted for the non-nickel workers; but an estimate of the expected proportions attributable to "other causes" and to "other respiratory disease" can be obtained from the national mortality data for men of the same ages in England and Wales during the same period. The estimated numbers are 22 and 25 out of 139 respectively. The number of lung cancer deaths among the nickel workers might also have been artificially increased if there had been a specific tendency to describe as nickel workers men who had died of lung cancer and who, after employment at the refinery, had taken up some other occupation. Evidence that a bias of this type may, in the case of coal-miners, 
contribute to the excess mortality which is recorded on death certificates for this occupation has been obtained by Heasman, Liddell, and Reid (1958). It is, however, unlikely that such a factor should have biased the present results to an important extent, since the excess mortality has been practically constant since 1938 (see Table 4) and has shown no tendency to increase since the disease was prescribed in 1949. It is concluded, therefore, that the only reasonable interpretation of the results is that the high proportion of lung cancer deaths among nickel workers was due to an excess mortality from the disease and that, in the period 1948-56, the risk of dying from the disease was approximately five times "normal".

Not all the workers appear to have been equally at risk. Of the 48 nickel workers whose deaths were attributed to lung cancer during this period, 28 , or $58 \%$, were described as having been employed directly on the process (that is, "processman " or " process worker"); on the other hand, the proportion of men whose deaths were attributed to causes other than cancer of the lung or nose and who were similarly described was somewhat smaller-54 out of 139 or $39 \%$. The numbers of deaths from lung cancer expected among the process and the nonprocess workers are estimated to have been 3.93 and 5.95 respectively, so that on this basis the risk among the process workers appears to have been approximately double that among the other employees (28 observed to 3.93 expected compared with 20 observed to 5.95 expected, ratios of $7 \cdot 1$ to 1 and 3.4 to 1). Some of the non-process workers are, however, likely to have been employed as process workers at some time previously or to have had some closer contact with the specific process (for example, gatekeeper, labourer, and fitter). The relative risks to these two groups cannot, therefore, be satisfactorily

TABLE 4

COMPARISON BETWEEN OBSERVED AND EXPECTED NUMBERS OF DEATHS FROM CANCER OF LUNG IN FOUR OCCUPATIONAL GROUPS IN 1938-47 AND 1948-56

\begin{tabular}{|c|c|c|c|c|c|}
\hline Period & No. of Deaths & $\begin{array}{c}\text { Nickel } \\
\text { Workers }\end{array}$ & $\begin{array}{c}\text { Men in Other } \\
\text { Selected } \\
\text { Occupations }\end{array}$ & $\begin{array}{c}\text { Steel } \\
\text { Workers }\end{array}$ & $\begin{array}{l}\text { Colliery } \\
\text { Workers }\end{array}$ \\
\hline $1938-47$ & $\begin{array}{l}\text { Expected from } \\
\text { the experience } \\
\text { of men in "all } \\
\text { other, occupa- } \\
\text { tions"" } \\
\text { Observed } \\
\text { Observed as \% } \\
\text { of expected }\end{array}$ & $\begin{array}{r}36 \\
1,379\end{array}$ & ${ }^{0}-$ & $\begin{array}{r}22 \\
168\end{array}$ & $20 \cdot 67$ \\
\hline 1948-56 & $\begin{array}{l}\text { Expected from } \\
\text { the experience } \\
\text { of men in "all } \\
\text { other, occupa- } \\
\text { tions" } \\
\text { Observed } \\
\text { Observed as \% } \\
\text { of expected }\end{array}$ & $\begin{array}{r}39 \\
666\end{array}$ & $\begin{array}{r}5 \\
117\end{array}$ & $\begin{array}{r}45 \\
119\end{array}$ & $\begin{array}{l}23 \\
40\end{array}$ \\
\hline
\end{tabular}

measured from the present data and it is possible that the real difference is much greater.

\section{Lung Cancer in Other Special Occupations}

In contrast to the nickel workers, some part of the discrepancy between the observed and expected numbers of lung cancer deaths among the colliery workers may be attributed to an abnormal death rate from "other causes". According to the preliminary data on occupational mortality in England and Wales in 1950 (Registrar General, 1954), the death rate from all causes other than lung cancer among coal-miners aged 20-64 years was $20 \%$ above the average for the whole country. If, therefore, the numbers of deaths from " other causes" among the coal-miners are reduced by one-sixth (20/120), the expected number of lung cancer deaths becomes 126.80 , and, in this case, the observed number is $58 \%$ of the expected. The mines in the area studied are, however, anthracite mines and anthracite miners in South Wales have suffered a higher mortality than other miners. In 1930-32, for example, the standardized mortality ratio for all coal workers below ground aged 20-65 years was 105, but it was 143 for the workers below ground in the anthracite mines of South Wales (Registrar General, 1938). If therefore, this difference has persisted in more recent periods the expected number of lung cancer deaths among miners should be reduced still further. The mortality from lung cancer among coal-miners in Britain has consistently been recorded as lower than that for all men and according to the occupational mortality data for 1950 was, at ages 20-64 years, $69 \%$ of the general rate. The present method of investigation would, therefore, appear to have provided a reasonably accurate estimate of mineworkers' mortality from this disease.

Lung cancer mortality among the five groups of workers included in " other selected occupations" will be discussed in another report.

\section{Nasal Cancer}

In the study of nasal cancer it is not possible to use quite the same technique, since the disease is normally very rare and the number of deaths shown in Table 1 due to nasal cancer among the men in " all other occupations" is very small. A more reliable estimate of the expected number of deaths might be obtained by using the whole group of nonnickel workers as a standard. This is vitiated, however, by the fact that the risk among the nickel workers appears to have been relatively so great that the inclusion of a small number of deaths of ex-nickel workers among the deaths of men who were last employed in some other occupation has 
artificially increased the mortality from nasal cancer among the other workers in the area. Thus, in the four areas studied there were 12 deaths from nasal cancer during the period 1948-56 among men who were not nickel workers at the time of their death. The relatives of 10 of them were traced and it was learnt that four had been employed at the nickel refinery at some time. Similarly, in the two areas for which information was available back to 1938 , four deaths from cancer of the nose were found to have occurred during the period 1938-47 among men who were not nickel workers at the time of death. Relatives of all these men were traced and it was discovered that three of them had previously been nickel workers. In all, therefore, at least seven out of the 16 non-nickel workers resident in the area who died of nasal cancer may at some time have been exposed to the particular hazard which is being studied.

In these circumstances, it is preferable to use the national data to provide an estimate of the expected mortality. Detailed figures have been published for the numbers of deaths attributed to a group of upper respiratory cancers consisting of cancer of the nose, nasal cavities, middle ear and accessory sinuses for each year since 1950, and figures for the total numbers of these cancers by sex have been published for the years 1940-49. Since the crude male death rate has been practically constant since 1942 (varying only from 5 to 6 per million), and since the deaths attributed to nasal cancer in Tables 1 and 2 include all the deaths which would have been classified by the Registrar General in this category-and no others-the national data provide a reasonable basis for comparison with the data collected in the present investigation. If, therefore, the whole male population of England and Wales is taken as the standard population and the same method of estimation is used as was used previously, estimates

TABLE 5

COMPARISON BETWEEN OBSERVED AND EXPECTED NUMBERS OF DEATHS FROM CANCER OF NOSE AMONG

\begin{tabular}{|c|c|c|c|}
\hline \multirow{2}{*}{ Population } & \multicolumn{2}{|c|}{$\begin{array}{l}\text { No. of Deaths from } \\
\text { Cancer of Nose }\end{array}$} & \multirow{2}{*}{$\begin{array}{c}\text { Ratio of } \\
\text { Numbers } \\
\text { Observed and } \\
\text { Expected }\end{array}$} \\
\hline & Observed & Expected & \\
\hline $\begin{array}{l}\text { Nickel workers: } \\
\text { Four areas, } 1948-56 \\
\text { Two areas, } 1938-47 \\
\text { All a areas available, } \\
\text { 1938-56 }\end{array}$ & $\begin{array}{l}13 \\
16 \\
29\end{array}$ & $\begin{array}{l}0.082 \\
0 \cdot 066 \\
0 \cdot 148\end{array}$ & $\begin{array}{l}159: 1 \\
242: 1 \\
196: 1\end{array}$ \\
\hline $\begin{array}{l}\text { Non-nickel workers: } \\
\text { Four areas, } 1948-56 \\
\text { Two areas, 1938-47 } \\
\text { All areas available }\end{array}$ & $\begin{array}{l}12^{*} \\
4^{*} \\
16^{*}\end{array}$ & $\begin{array}{r}8.279 \\
2 \cdot 132 \\
10.411\end{array}$ & 二 \\
\hline
\end{tabular}

*Including several deaths among men with a history of previous employment in the nickel refinery: four in the period 1948-56 and three in 1938-47. of the expected numbers of deaths from nasal cancer can be obtained. The results are shown in Table 5 . From Table 5 it appears that the mortality from nasal cancer among the nickel workers during the period 1948-56 has been about 150 times higher than normal.

As previously with lung cancer, the risk does not appear to have been distributed equally among all the workers. Of the 29 nickel workers whose deaths were attributed to nasal cancer during the whole period 1938-56, 19 , or $66 \%$, were described as having been last employed before death directly on the process; the proportion of men who were similarly described and whose deaths were attributed to causes other than cancer of the lung or nose was 99 out of 231 , or $43 \%$. The numbers of deaths from nasal cancer expected among these two groups of workers are estimated to have been 0.064 and 0.084 , so that on this basis the risk among the process workers appears to have been approximately two and a half times that among the other employees (19 observed to 0.064 expected compared with 10 observed to 0.084 expected, ratios of approximately 300 to 1 and 120 to 1 ). It must, however, be stressed again that the present data are unsatisfactory for estimating the relative risks among different occupational groups within the industry and the real difference may have been very much greater.

The total number of deaths registered among nonnickel workers during the whole period 1938-56 is somewhat larger than the expected number (16 against 10.4), but seven of these deaths occurred in men who are known to have been nickel workers previously. If these seven deaths are excluded the agreement is close and it may be concluded that the estimates of the numbers of deaths expected are reasonably accurate.

\section{Secular Changes in Risk from Cancer of the Lung and Nose}

To test the extent to which the risks have altered it is necessary to examine data collected over a long period of years since the induction period before the appearance of cancer is generally long. In the present case, data adequate for this purpose are available for only two of the four areas which were originally studied; these have been shown in Table 2. The men who were employed in " all other occupations" and were resident in these two areas have been used as the standards and the expected numbers of deaths attributable to cancer of the lung have been calculated by the technique described previously (working, however, with 10-year instead of five-year age groups, because of the smaller numbers). The results obtained are shown in Table 4. From these figures it would appear that 
the specific risk of lung cancer in the industry has decreased from about 14 times " normal" to about seven times " normal". This change, however, cannot be regarded as evidence of a decrease in risk among the nickel workers since the "normal" risk of lung cancer increased substantially during the period in question. In fact the excess over expectation of lung cancer deaths among the nickel workers was 3.3 per year during 1938-47 and 3.7 per year during 1948-56. Similarly, if the national data are used to estimate the numbers of deaths from nasal cancer expected in the two periods, it appears that the average excesses were 1.6 and 1.4 deaths per year. Clearly cases are still occurring and there has not as yet been any substantial change in their number.

On the other hand, from the data in Table 6, it is clear that the distribution of the ages at death has changed for both types of cancer. The change is particularly striking for cancer of the nose, for which the average age at death has increased by 6.2 years from 59.6 to 65.8 years. For cancer of the lung the increase is less marked, but it is still appreciable (an average increase of 3.3 years from 57.0 to 60.3 years). These changes may be regarded as evidence that the greatest risk occurred at some time in the past; for, in this situation, the average age of the men who suffered the heaviest exposure, and who may be presumed to suffer the heaviest specific mortality, must be expected to increase steadily with the passage of time. Further, for neither type of cancer is there any evidence of an increased mortality among men who were aged less than 50 years during the period 1948-56. It is clear, therefore, that there is no present evidence of any excess risk among men who, by virtue of their age, must have begun to be employed at the refinery after 1924. This is substantiated by Morgan (1958) who has made a detailed study of the occupational histories of the employees known to the industry to have died of cancer. He has found that none of those who started to work at the refinery after 1924 has died

TABLE 6

AGE DISTRIBUTION OF DEATHS FROM CANCER OF LUNG AND OF NOSE AMONG NICKEL WORKERS IN 1938-47 AND OF NOSE AMONG 1948-56

\begin{tabular}{c|c|c|c|c}
\hline \multirow{2}{*}{$\begin{array}{c}\text { Age } \\
\text { (years) }\end{array}$} & \multicolumn{2}{|c|}{ Cancer of Lung } & \multicolumn{2}{c}{ Cancer of Nose } \\
\cline { 2 - 5 } & $1938-47$ & $1948-56$ & $1938-47$ & $1948-56$ \\
\hline Under 45 & 0 & 0 & 0 & 0 \\
$45-$ & 4 & 1 & 0 & 0 \\
$50-$ & 10 & 8 & 2 & 1 \\
$55-$ & 10 & 7 & 7 & 1 \\
$60-$ & 6 & 14 & 5 & 2 \\
$65-$ & 3 & 7 & 2 & 7 \\
$70-$ & 0 & 0 & 0 & 1 \\
75 or more & 0 & 0 & 13 \\
\hline All ages & 36 & 39 & 16 & 13 \\
\hline
\end{tabular}

of cancer of the nose and only six of them have died of cancer of the lung. An estimate based on the national mortality rates for lung cancer suggested that if the risk had been entirely eliminated the expected number of lung cancer deaths would have been nine.

\section{Total Number of Respiratory Cancer Deaths Reported}

The deaths from cancer reported in Tables 1 and 2 must be presumed to include a large proportion of the deaths due to cancer of the lung and nose which have been reported previously as occurring among nickel workers (Chief Inspector of Factories, 1952). The deaths in the Chief Inspector's report had, however, all occurred before the end of 1950 so that they do not include the 33 deaths from lung cancer and the 12 deaths from nasal cancer found in the present inquiry to have occurred among nickel workers and ex-nickel workers during the six years 1951-56. The total numbers of deaths now known to have occurred from cancer of the lung and nose during the period 1923 to 1956 are, therefore, at least 126 and 62 respectively.

In contrast, it may be noted that, in the present inquiry, only one nickel worker was found to have died from cancer of the larynx during the whole period 1938-56, and no other similar death has been reported for any earlier period.

\section{Summary}

Cancer of the lung and cancer of the nose have been prescribed as industrial diseases when they occur among certain classes of nickel workers. There is, however, no published evidence to show the size of the risks nor the extent to which they have been eliminated.

Data were collected from the records of deaths held by the medical officers of health for the districts in which workers at a nickel refinery lived. From the ratio of deaths attributed to lung cancer to deaths from causes other than cancer of the lung and nose among the other men resident in the same area an estimate was made of the number of lung cancer deaths which would be expected to have occurred among men employed in four specified occupational groups. During the years 1948-56, there were 139 deaths from " other causes" among nickel workers and 48 from lung cancer; the expected number of lung cancer deaths among them was 9.9. The excess did not appear to be due to a bias in favour of diagnosing lung cancer among nickel workers, and it is concluded that during 1948-56 the risk of nickel workers dying from the disease was approximately five times " normal". 
During 1948-56, 13 deaths among nickel workers were due to cancer of the nose. An estimate based upon the national mortality data suggested that the expected number of deaths was less than $0 \cdot 1$ and that the nickel workers' risk of dying from the disease was approximately 150 times " normal ".

Comparison of the data for 1938-47 with those for 1948-56 provided no evidence of any substantial change in the annual number of deaths due to these specific diseases. There was, however, an increase in the average age at which death occurred and no excess in mortality was apparent at ages under 50 . It is, therefore, reasonable to believe that the hazard has been largely or completely removed in the last 35 years.

The total numbers of deaths from these two diseases which are now known to have occurred among British nickel workers are: cancer of the lung, 126; cancer of the nose, 62.
I am most grateful to Dr. G. M. Davies, Dr. E. B. Meyrick, and Dr. H. R. Stubbins, medical officers of health, for making their records available for examination and for the assistance given by them and by their staffs. I am also very grateful for the assistance of the health visitors, who succeeded in obtaining occupational histories from such a high proportion of those non-nickel workers who had died of cancer of the nose, and to Miss K. Jones and Miss J. Parrish who extracted the greater part of the data.

\section{REFERENCES}

Amor, A. J. (1939). Bericht über den VIII. internationalen Kongress für Unfall medizin und Berufskrankheiten, Frankfurt A-M, 1938, Vol 2 p 941 . Thieme, Leipzig.

Chief Inspector of Factories (1952). Annual Report of the Chief Inspector of Factories for the Year 1950, p. 145. H.M.S.O., London.

London.
Heasman, M. A., Liddell, F. D. K., and Reid, D. D. (1958). Brit. J. industr. Med., 15, 141.

Løken, A. C. (1950). T. norske Laegeforen., 70, 376.

Morgan, J. Gwynne (1958). Brit. J. industr. Med., 15, 221

Registrar General (1938). Decennial Supplement England and Wales, 1931. Part IIA. Occupational Mortality. H.M.S.O., Lon-

don. (1954). Decennial Supplement England and Wales, 1951. Part I. Occupational Mortality. H.M.S.O., London. 